\title{
NOTTINGHAM \\ TRENT UNIVERSITY
}

\section{DISCUSSION PAPERS}

\section{N}

ECONOMICS

No. 2009/4 ISSN 1478-9396
IS THERE A TRADE-OFF BETWEEN INCOME
INEQUALITY AND CORRUPTION? EVIDENCE FROM
LATIN AMERICA
Stephen DOBSON and Carlyn RAMLOGAN
June 2009




\section{DISCUSSION PAPERS IN ECONOMICS}

The economic research undertaken at Nottingham Trent University covers various fields of economics. But, a large part of it was grouped into two categories, Applied Economics and Policy and Political Economy.

This paper is part of the new series, Discussion Papers in Economics.

Earlier papers in all series can be found at:

http://www.ntu.ac.uk/research/academic_schools/nbs/working_papers/index.html

Enquiries concerning this or any of our other Discussion Papers should be addressed to the Editor:

Dr Juan Carlos Cuestas

Division of Economics

Nottingham Trent University

Burton Street

Nottingham, NG1 4BU

UNITED KINGDOM

Email: juan.cuestas@ntu.ac.uk 


\title{
Is there a trade-off between income inequality and corruption? Evidence from Latin America
}

\author{
Stephen Dobson \\ $\&$ \\ Carlyn Ramlogan \\ Division of Economics, Nottingham Trent University, UK
}

\begin{abstract}
Conventional economic thinking says corruption and income inequality are positively related. In contrast, this study finds that lower corruption is associated with higher income inequality. The finding of a trade-off is not unexpected in the context of Latin America, for two reasons. First, Latin America has a large informal sector and corruption-reducing polices impose a transaction cost on this sector whose members are among the poorest. Second, redistributive measures, promoted by corrupt elements in society, are often cut back with institutional reform and this serves to worsen inequality. The results imply that corruption-reducing policies aimed at lowering inequality may be misguided.
\end{abstract}

Key words: corruption, Latin America, income inequality, instrumental variables, panel data. JEL classification: O15, O54 


\section{Introduction}

Conventional economic thinking says that lower corruption reduces income inequality through various channels (e.g., Gupta et al, 2002; Gyimah-Brempong, 2002; GyimahBrempong and Muñoz de Camacho, 2006). However, Chong and Calderon (2000) find a nonmonotonic relationship between corruption and inequality in a cross sectional study of many countries and conclude that the presence of a large informal sector may be the reason why the expected relationship does not hold for some countries. One way to explore this further is to study corruption and inequality for a group of countries that have a sizeable informal sector and where there is a focus on institutional reform. Latin America seems a good choice because the informal sector plays a significant role in most labour markets, contributing 25$35 \%$ of aggregate output. Also, in recent times many countries have been introducing corruption-reducing policies and other institutional reforms ${ }^{1}$.

This paper examines the corruption-inequality relationship in Latin America. The novel feature of the paper is the finding of robust evidence of a trade-off between corruption and inequality. This result is important not only because it is consistent with the idea that the corruption-inequality relationship may be different where there is a large informal sector but also because it suggests policy reform measures in Latin America may be misguided. The rest of the paper is structured as follows. Section 2 describes the empirical methodology and Section 3 reports the results. Section 4 concludes.

\section{Econometric investigation}

Econometric estimation is conducted using four-year panel data over the period 1984-2003 for 19 Latin American countries. ${ }^{2}$ The empirical specification in (1) is similar to that in previous empirical research (e.g. Barro, 2000; Lundberg and Squire, 2003): 


$$
I_{i t}=X_{i t} \beta+A_{i}+\varepsilon_{i t} \quad(i=1, \ldots . n ; t=1, \ldots \ldots . T)
$$

where $I$ is a measure of income inequality for country $i$ at time $t . X_{i t}$ is a vector of explanatory variables that vary across time and countries. The parameter $A_{i}$ contains a constant and individual-specific variables that are invariant over time and $\varepsilon_{i t}$ is the classical error term.

The dependent variable is the Gini coefficient. Inequality data is drawn from the United Nations World Income Inequality Database (WIID) (UNU-WIDER, 2005). ${ }^{3}$ We use dummy variables to control for the definition of income and the survey unit. The measure of corruption is the widely used International Country Risk Guide (ICRG) corruption index. The ICRG measure takes values from zero (most corrupt) to six (least corrupt). ${ }^{4}$

As in other studies of inequality (e.g., Bourguignon and Morrisson, 1998; Morley, 2000; Gupta et al, 2002; Reuveny and Li, 2003; Albanesi, 2007) the model also includes the following explanatory variables: real output per capita $(\lg d p)$, real output per capita squared $\left(\lg d p^{2}\right)$, primary (primary) and secondary (secondary) gross school enrolment rates, the share of agriculture in total output ( $a g g d p)$, the ratio of broad money to output ( $m 2 g d p)$, domestic credit to the private sector (dcps), the distribution of land resources (land), openness of the economy (trade), foreign direct investment (fdi), inflation (inflation), the concentration of natural resources (natres), privatisation (priv) and interaction terms. Data for these variables is taken from the Penn World Tables, Version 6.1 (Heston, Summers and Aten, 2002), World Bank World Development Indicators (2003) and Frankema (2005).

To deal with potential endogeneity an instrumental variable (IV) methodology is used. In other research several instruments for corruption have been used (e.g., Gupta, 2002; Gyimah-Brempong and Muñoz de Camacho, 2006). In the case of Latin America there is a limited availability of suitable instruments, which restricts our choice to two: democracy and government consumption. Tests are undertaken to ensure that the instruments are valid and 
relevant. Panel based tests for serial correlation and heteroskedasticity are also conducted (Woolridge, 2002).

\section{Results}

The results of estimating (1) using OLS are shown in Table 1. Several different specifications are shown in columns (1) to (4). The random effects model is rejected in favour of the fixed effects model. The sign on the corruption coefficient (corrupt) is positive in column (1). The higher is the corruption index (lower is corruption), the higher is inequality. The positive sign persists for alternative model specifications as indicated in the other columns of Table 1 . This result indicates there is a trade-off between inequality and corruption.

Table 2 reports results using an alternative dependent variable, the share of income in the lowest quintile. The results show that as corruption falls the percentage of people in the lowest income group rises (inequality worsens). This result persists over alternative specifications. Table 3 shows the results for the IV estimation. ${ }^{5}$ The corruption index is again positive. Based on the $F-1 s t$ statistic and the test for overidentifying restrictions, we conclude that the instruments are relevant and valid. The finding of a trade-off between inequality and corruption appears to be robust.

The finding of a trade-off can be explained as follows. Institutional reform is likely to exacerbate inequality in countries where there is a large informal sector. Firms in this sector have low operating costs arising from their lack of compliance to rules and regulations. It is for this reason that the sector tends to employ the poorest members of society. Since compliance comes with institutional reform and corruption reducing measures, firms will incur rising costs. Furthermore, the actual process of reform requires better trained personnel and support infrastructure, necessitating new taxes. Higher costs of production, new taxes and more vigilant policing will have a direct impact on employment in the informal sector. ${ }^{6}$ 
A second plausible explanation for the trade-off focuses on the impact of reform on redistributive measures. In many developing countries income redistribution policies are promoted by corrupt elements in society whose primary interest is political power. ${ }^{7}$ For example, "special government projects" designed to increase employment of the poor are promoted by particular groups who can benefit from such projects (e.g., construction of roads and housing development schemes). These projects employ manual labourers who would otherwise have been unemployed. As countries introduce institutional reform, rent seeking is reduced since "special government projects" are more stringently assessed and the tendering process becomes more competitive. Projects which would have been undertaken under a corrupt system are not undertaken now because they are not economically viable. Further, contracts which are in operation may be stopped or not renewed. It is also likely that projects are more capital intensive.

\section{Conclusion}

This paper finds evidence of a trade-off between income inequality and corruption using panel data for Latin America. The result is robust to different measures of inequality and different model specifications and estimation methods. Our key finding is consistent with the idea that the corruption-inequality relationship may be different where there is a large informal sector, as in Latin America. As governments implement institutional reform, a transaction cost is imposed on the informal sector whose members are among the poorest in society. Reform also involves a cutting back on redistributive measures, promoted by corrupt elements, and this serves to worsen inequality. The finding of a trade-off between inequality and corruption is also consistent with work that has examined the impact of institutional reform, such as trade and financial reforms, on inequality in the region. 


\section{References}

Albanesi, S., 2007, Inflation and inequality, Journal of Monetary Economics 54, 1088-1114.

Alesina, A. and G. Angelotos, 2005, Corruption, inequality and fairness, Journal of Monetary Economics 52, 1227-1244.

Barro, R.J., 2000, Inequality and growth in a panel of countries, Journal of Economic Growth $5,5-32$.

Bourguignon, F. and C. Morrison, 1998, Inequality and development: the role of dualism, Journal of Development Economics 57, 233-257.

Chong, A. and C. Calderon, 2000, Institutional quality and distribution of income, Economic Development and Cultural Change 42, 761-786.

Frankema, E., 2005, The colonial origins of inequality: a global investigation of land distribution. Presented at a symposium on poverty and inequality in Latin America, IberoAmerican Institute for Economic Research.

Gupta, S., Davoodi, H. and R. Alonso-Terme, 2002, Does corruption affect income inequality and poverty?, Economics of Governance 3, 23-45.

Gyimah-Brempong, K., 2002, Corruption, economic growth and income inequality in Africa, Economics of Governance 3, 183-209.

Gyimah-Brempong, K. and S. Muñoz de Camacho, 2006, Corruption, growth and income distribution: are there regional differences?, Economics of Governance 7, 245-269.

Heston, A.R., Summers, R., and B. Aten, 2002, PennWorld Table Version 6.1, Center for International Comparisons at the University of Pennsylvania (CICUP), October.

Lambsdorff, J., 2006, The validity and precision of subjective indicators (CPI), in C. Sampford, A. Shacklock, C. Connors, and F. Galtung, eds, Measuring Corruption, Ashgate, Aldershot, pp.81-99. 
Lundberg, M. and L. Squire, 2003, The simultaneous evolution of growth an equality, Economic Journal 113, 326-344.

Morley, S., 2000, The effects of growth and economic reform on income distribution in Latin America, CEPAL Review 71, August, 23-40.

Reuveny, R. and Q. Li, 2003, Economic openness, democracy and income inequality: an empirical analysis, Comparative Political Studies 36, 575-601.

Woolridge, J.M., 2002, Econometric analysis of cross section and panel data. (MIT Press, Pennsylvania, Cambridge, MA).

World Bank, 2005, World Development Indicators CD-ROM. (The World Bank: Washington, D.C., US). 
Table 1: OLS estimation results (Gini index)

\begin{tabular}{|c|c|c|c|c|}
\hline Dependent variable: Gini index & (1) & (2) & (3) & (4) \\
\hline lgdp & $\begin{array}{c}-100.812 \\
{[0.254]}\end{array}$ & $\begin{array}{c}-39.460 \\
{[0.581]}\end{array}$ & $\begin{array}{c}-97.718 \\
{[0.157]}\end{array}$ & $\begin{array}{c}-5.094 \\
{[0.148]}\end{array}$ \\
\hline $\operatorname{lgd} p^{2}$ & $\begin{array}{c}5.419 \\
{[0.283]}\end{array}$ & $\begin{array}{c}1.853 \\
{[0.639]}\end{array}$ & $\begin{array}{c}5.377 \\
{[0.165]}\end{array}$ & \\
\hline primary & $\begin{array}{c}-0.1136^{* *} \\
{[0.040]}\end{array}$ & $\begin{array}{c}-0.137 * * \\
{[0.051]}\end{array}$ & $\begin{array}{c}-0.133 * * \\
{[0.055]}\end{array}$ & $\begin{array}{c}-0.133 * * \\
{[0.048]}\end{array}$ \\
\hline secondary & $\begin{array}{l}0.123 * * \\
{[0.024]}\end{array}$ & $\begin{array}{l}0.087^{*} \\
{[0.091]}\end{array}$ & $\begin{array}{l}0.081^{*} \\
{[0.092]}\end{array}$ & $\begin{array}{l}0.099^{*} \\
{[0.074]}\end{array}$ \\
\hline aggdp & & $\begin{array}{c}-0.111 \\
{[0.4145]}\end{array}$ & & \\
\hline m2gdp & & $\begin{array}{l}0.195^{* *} \\
{[0.030]}\end{array}$ & $\begin{array}{c}0.136 * * \\
{[0.0461]}\end{array}$ & \\
\hline dcps & $\begin{array}{l}0.086 * * \\
{[0.027]}\end{array}$ & & & $\begin{array}{l}0.091 * * \\
{[0.044]}\end{array}$ \\
\hline trade & $\begin{array}{c}0.166 * * * \\
{[0.000]}\end{array}$ & $\begin{array}{l}0.123 * * \\
{[0.024]}\end{array}$ & $\begin{array}{c}0.224 * * * \\
{[0.000]}\end{array}$ & $\begin{array}{c}0.167 * * * \\
{[0.003]}\end{array}$ \\
\hline inflation & & $\begin{array}{c}0.000 \\
{[0.603]}\end{array}$ & & \\
\hline natres & & $\begin{array}{c}0.262 \\
{[0.235]}\end{array}$ & $\begin{array}{c}0.118 \\
{[0.372]}\end{array}$ & \\
\hline land & $\begin{array}{c}36.049 * * \\
{[0.035]}\end{array}$ & $\begin{array}{l}31.655 \\
{[0.223]}\end{array}$ & & $\begin{array}{l}31.361 * \\
{[0.077]}\end{array}$ \\
\hline corrupt & $\begin{array}{l}1.566 * * \\
{[0.024]}\end{array}$ & $\begin{array}{l}1.424 * * \\
{[0.026]}\end{array}$ & $\begin{array}{c}2.530 * * \\
{[0.051]}\end{array}$ & $\begin{array}{c}1.831 * * * \\
{[0.007]}\end{array}$ \\
\hline corrupt*trade & & & $\begin{array}{l}-0.026^{*} \\
{[0.093]}\end{array}$ & \\
\hline trade*natres & & $\begin{array}{r}-0.0043 \\
(0.284)\end{array}$ & & \\
\hline corrupt*priv & & & & $\begin{array}{l}-0.216^{*} \\
{[0.057]}\end{array}$ \\
\hline fdi & & $\begin{array}{l}0.1518 \\
{[0.109]}\end{array}$ & & \\
\hline priv & & $\begin{array}{c}0.180 \\
{[0.222]}\end{array}$ & & $\begin{array}{l}0.705^{*} \\
{[0.090]}\end{array}$ \\
\hline constant & $\begin{array}{l}479.160 \\
{[0.214]}\end{array}$ & $\begin{array}{l}246.166 \\
{[0.443]}\end{array}$ & $\begin{array}{l}465.830 \\
{[0.110]}\end{array}$ & $\begin{array}{c}53.807 \\
{[0.1794]}\end{array}$ \\
\hline $\begin{array}{l}\text { F- test } \\
\text { (p-value) }\end{array}$ & $\begin{array}{r}23.3657 \\
{[0.000]}\end{array}$ & $\begin{array}{c}24.1032 \\
{[0.000]}\end{array}$ & $\begin{array}{r}23.3657 \\
{[0.000]}\end{array}$ & $\begin{array}{l}21.895 \\
{[0.000]}\end{array}$ \\
\hline $\begin{array}{l}\text { Hausman test } \\
\text { (p-value) }\end{array}$ & $\begin{array}{c}15.803 \\
(0.0453)\end{array}$ & $\begin{array}{c}24.167 \\
(0.0437)\end{array}$ & $\begin{array}{c}24.198 \\
(0.0040)\end{array}$ & $\begin{array}{l}16.901 \\
{[0.034]}\end{array}$ \\
\hline Adjusted $\mathrm{R}^{2}$ & 0.527 & 0.548 & 0.563 & 0.537 \\
\hline Number of observations & 70 & 73 & 70 & 66 \\
\hline
\end{tabular}

p-values are in square brackets.

$*$ significant at $10 \%$;* significant at 5\%; *** significant at $1 \%$

Fixed effects not reported 
Table 2: OLS estimation results (\% share in lowest quintile)

\begin{tabular}{|c|c|c|c|c|}
\hline $\begin{array}{l}\text { Dependent variable: percentage } \\
\text { share of population in lowest } \\
\text { quintile }\end{array}$ & (1) & (2) & (3) & (4) \\
\hline \multirow[t]{2}{*}{$\operatorname{lgdp}$} & -28.476 & 14.740 & 0.506 & -21.941 \\
\hline & {$[0.551]$} & {$[0.754]$} & {$[0.668]$} & {$[0.601]$} \\
\hline \multirow[t]{2}{*}{$\operatorname{lgdp}{ }^{2}$} & 1.500 & -1.260 & & 1.123 \\
\hline & {$[0.584]$} & [0.644] & & {$[0.661]$} \\
\hline \multirow[t]{2}{*}{ primary } & $-0.225^{* *}$ & $-0.184^{*}$ & $-0.193 * *$ & $-0.215^{* *}$ \\
\hline & {$[0.013]$} & {$[0.076]$} & {$[0.0377]$} & {$[0.041]$} \\
\hline \multirow[t]{2}{*}{ secondary } & $0.146 * *$ & $0.109^{*}$ & & $0.142^{*}$ \\
\hline & {$[0.049]$} & [0.091] & & {$[0.070]$} \\
\hline \multirow[t]{2}{*}{ aggdp } & & -0.471 & & \\
\hline & & {$[0.128]$} & & \\
\hline \multirow[t]{2}{*}{ M2gdp } & & $0.119 * *$ & $0.106^{*}$ & \\
\hline & & {$[0.051]$} & {$[0.067]$} & \\
\hline \multirow[t]{2}{*}{ dcps } & $0.124 * * *$ & & & $0.121 * * *$ \\
\hline & {$[0.003]$} & & & {$[0.003]$} \\
\hline \multirow[t]{2}{*}{ trade } & $0.080 * *$ & 0.045 & & $0.075^{*}$ \\
\hline & {$[0.024]$} & {$[0.556]$} & & {$[0.091]$} \\
\hline \multirow[t]{2}{*}{ inflation } & & 0.000 & 0.000 & \\
\hline & & [0.296] & {$[0.791]$} & \\
\hline \multirow[t]{2}{*}{ natres } & $0.291 * *$ & 0.361 & $0.663 * * *$ & \\
\hline & {$[0.045]$} & {$[0.267]$} & {$[0.005]$} & \\
\hline \multirow[t]{2}{*}{ land } & & 43.9071 & & $67.931 * * *$ \\
\hline & & {$[0.162]$} & & {$[0.001]$} \\
\hline \multirow[t]{2}{*}{ corrupt } & $1.602 * *$ & $1.465^{* *}$ & $1.577 * *$ & $1.753 * *$ \\
\hline & {$[0.041]$} & {$[0.061]$} & {$[0.048]$} & {$[0.015]$} \\
\hline corrupt*trade & & & $\begin{array}{l}-0.011 \\
{[0.4311}\end{array}$ & \\
\hline trade*natres & & $\begin{array}{c}-0.025 \\
{[0.768]}\end{array}$ & & \\
\hline corrupt*priv & & & & $\begin{array}{c}0.118 \\
{[0.481]}\end{array}$ \\
\hline \multirow[t]{2}{*}{ fdi } & & $0.144^{*}$ & $0.376^{* *}$ & \\
\hline & & [0.053] & {$[0.041]$} & \\
\hline \multirow[t]{2}{*}{ priv } & & $0.269^{*}$ & $0.344 * *$ & $0.446^{* * *}$ \\
\hline & & {$[0.061]$} & {$[0.043]$} & {$[0.003]$} \\
\hline \multirow[t]{2}{*}{ constant } & 80.994 & 56.818 & 46.887 & 135.33 \\
\hline & {$[0.711]$} & {$[0.541]$} & {$[0.751]$} & {$[0.524]$} \\
\hline F- test & 15.321 & 21.71 & 23.16 & 19.013 \\
\hline (p-value) & {$[0.000]$} & {$[0.000]$} & {$[0.000]$} & {$[0.000]$} \\
\hline Hausman test & 23.470 & 33.481 & 19.131 & 24.940 \\
\hline (p-value) & {$[0.003]$} & {$[0.001]$} & {$[0.021$} & {$[0.000]$} \\
\hline Adjusted $\mathrm{R}^{2}$ & 0.631 & 0.663 & 0.624 & 0.668 \\
\hline Number of observations & 61 & 57 & 58 & 59 \\
\hline
\end{tabular}


Table 3: IV estimation results

\begin{tabular}{|c|c|c|c|c|}
\hline Dependent variable: & Gini index & Gini index & $\begin{array}{l}\% \text { of pop in } \\
\text { lowest quintile }\end{array}$ & $\begin{array}{l}\% \text { of pop in } \\
\text { lowest quintile }\end{array}$ \\
\hline $\operatorname{lgdp}$ & $\begin{array}{r}-170.542 \\
{[0.2526]}\end{array}$ & $\begin{array}{l}-93.279 \\
{[0.376]}\end{array}$ & $\begin{array}{c}-166.918 \\
{[0.341]}\end{array}$ & $\begin{array}{l}-78.856 \\
{[0.545]}\end{array}$ \\
\hline $\operatorname{lgdp}{ }^{2}$ & $\begin{array}{c}9.394 \\
{[0.171]}\end{array}$ & $\begin{array}{c}5.210 \\
{[0.881]}\end{array}$ & $\begin{array}{c}9.464 \\
{[0.391]}\end{array}$ & $\begin{array}{c}4.465 \\
{[0.553]}\end{array}$ \\
\hline primary & $\begin{array}{c}-0.175 * * \\
{[0.045]}\end{array}$ & $\begin{array}{c}-0.160^{*} \\
{[0.08]}\end{array}$ & $\begin{array}{c}-0.218 * * * \\
{[0.009]}\end{array}$ & $\begin{array}{c}-0.183 * * \\
{[0.041]}\end{array}$ \\
\hline secondary & $\begin{array}{l}0.164 * * \\
{[0.015]}\end{array}$ & $\begin{array}{l}0.113^{*} \\
{[0.095]}\end{array}$ & $\begin{array}{c}0.2583 * * * \\
{[0.001]}\end{array}$ & \\
\hline aggdp & & $\begin{array}{l}-0.042 \\
{[0.868]}\end{array}$ & & $\begin{array}{l}-0.287 \\
{[0.357]}\end{array}$ \\
\hline M2gdp & & $\begin{array}{l}0.144^{*} \\
{[0.091]}\end{array}$ & & $\begin{array}{l}0.147^{*} \\
{[0.098]}\end{array}$ \\
\hline land & $\begin{array}{c}43.318^{* *} \\
{[0.026]}\end{array}$ & $\begin{array}{l}27.433 \\
{[0.138]}\end{array}$ & & \\
\hline corrupt & $\begin{array}{l}3.837 * * \\
{[0.050]}\end{array}$ & $\begin{array}{l}3.168^{*} \\
{[0.063]}\end{array}$ & $\begin{array}{l}4.254 * * \\
{[0.045]}\end{array}$ & $\begin{array}{l}4.464 * * \\
{[0.047]}\end{array}$ \\
\hline deps & $\begin{array}{c}0.0807 * * \\
{[0.049]}\end{array}$ & & $\begin{array}{l}0.078^{* *} \\
{[0.055]}\end{array}$ & \\
\hline trade & $\begin{array}{c}0.145 * * * \\
{[0.000]}\end{array}$ & $\begin{array}{c}0.134 * * * \\
{[0.003]}\end{array}$ & $\begin{array}{l}0.055^{* *} \\
{[0.078]}\end{array}$ & \\
\hline inflation & & $\begin{array}{c}-0.000 \\
{[0.3410]}\end{array}$ & & $\begin{array}{l}-0.001 \\
{[0.648]}\end{array}$ \\
\hline natres & & $\begin{array}{l}0.2938 \\
{[0.154]}\end{array}$ & $\begin{array}{c}0.487 * * * \\
{[0.000]}\end{array}$ & $\begin{array}{l}0.813 * * \\
{[0.039]}\end{array}$ \\
\hline land & & $\begin{array}{l}27.433 \\
{[0.134]}\end{array}$ & & \\
\hline fdi & & $\begin{array}{c}-0.017 \\
{[0.883]}\end{array}$ & & $\begin{array}{c}0.0274 \\
{[0.812]}\end{array}$ \\
\hline priv & & $\begin{array}{l}-0.081 \\
{[0.654]}\end{array}$ & & $\begin{array}{c}0.482 \\
{[0.112]}\end{array}$ \\
\hline constant & $\begin{array}{l}773.542 \\
{[0.159]}\end{array}$ & $\begin{array}{l}442.283 \\
{[0.344]}\end{array}$ & $\begin{array}{c}775.09 \\
{[0.3410]}\end{array}$ & $\begin{array}{l}388.246 \\
{[0.483]}\end{array}$ \\
\hline$F-1$ st F-statistic & 13.139 & 9.551 & 14.623 & 8.55 \\
\hline $\begin{array}{l}\text { Test for overidentifiying } \\
\text { restrictions }\end{array}$ & 0.353 & 2.33 & 0.652 & 3.541 \\
\hline Adjusted $\mathrm{R}^{2}$ & 0.529 & 0.545 & 0.614 & 0.621 \\
\hline Number of observations & 68 & 62 & 61 & 58 \\
\hline
\end{tabular}

p-values are in square brackets.

$*$ significant at $10 \% ; * *$ significant at $5 \%$; *** significant at $1 \%$

Fixed effects not reported 


\section{Notes}

${ }^{1}$ This set of reforms is collectively known in Latin America as "second generation reforms". Policy also reflects to a lesser extent public concern over corruption and income inequality (Latinobarometro, 2003; see http://www.latinobarometro.org).

${ }^{2}$ Countries included in the sample are: Argentina, Bolivia, Brazil, Chile, Colombia, Costa Rica, Dominican Republic, Ecuador, Guatemala, Honduras, Jamaica, Mexico, Nicaragua, Panama, Paraguay, Peru, El Salvador, Uruguay, and Venezuela.

${ }^{3}$ Available at http://www.wider.unu.edu/wiid/wiid.htm

${ }^{4}$ This measure has been criticised by Lambsdorff (2006) on the grounds that the index measures the political risk of corruption. The problem with using an alternative measure, such as the Corruption Perception Index (CPI), is data is not available for the entire study period. We did experiment with the CPI for a sub period where data is available (1997-2003). The sign of the corruption variable (cpi) is positive (and near to being significant).

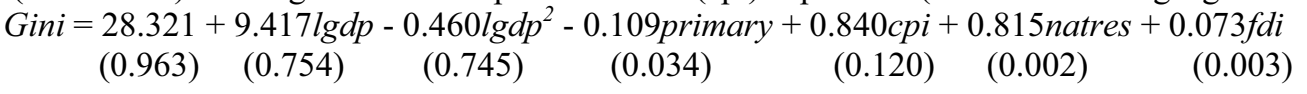
(0.963)
$(0.754)$
$(0.120)$
$(0.002)$

$$
\begin{array}{ccc}
-0.066 \text { trade } & -0.193 \text { priv }-21.037 \text { land } \\
(0.280) & (0.132) & (0.3317)
\end{array}
$$

$$
\mathrm{R}^{2}=0.537 \quad \text { Hausman }=18.756(0.027) \quad \text { F-test }=17.407(0.0000) \quad \mathrm{n}=51
$$

$\mathrm{p}$-values are in parentheses

${ }^{5}$ Dynamic panel estimation would be an ideal procedure to adopt given the limited choice of instrumental variables. However, missing observations and the fact that the Arellano-Bond method involves differencing the variables and using lags as instruments, would leave us with too few observations.

${ }^{6}$ Using cross section data, Chong and Calderon (2000) find a non-monotonic relationship between institutional quality and inequality. They allude to the presence of a political Kuznets curve. We tried a squared term for the corruption variable but it was not significant.

${ }^{7}$ Support for this view can be found in Alesina and Angeletos (2005) who state that corruption helps to promote support for redistributive policies. 


\section{DISCUSSION PAPERS IN ECONOMICS}

2009/3 Juan Carlos Cuestas and Luís Alberiko Gil-Alana, Further evidence on the PPP analysis of

2009/2 the Australian dollar: non-linearities, structural changes and fractional integration

Estefanía Mourelle and Juan Carlos Cuestas, Inflation persistence and asymmetries:

2009/1 Evidence for African countries

Juan Carlos Cuestas and Barry Harrison, Further evidence on the real interest rate parity

2008/16 hypothesis in Central and Eastern European Countries: unit roots and nonlinearities

2008/15 prices

Simeon Coleman, Inflation persistence in the Franc Zone: evidence from disaggregated

2008/14 prices

Peter Dawson and Stephen Dobson, The influence of social pressure and nationality on individual decisions: evidence from the behaviour of referees

2008/13 Juan Carlos Cuestas and Barry Harrison, Testing for stationarity of inflation in Central and Eastern European Countries

2008/12 Juan Carlos Cuestas and Dean Garratt, Is real GDP per capita a stationary process? Smooth transitions, nonlinear trends and unit root testing

2008/11 Antonio Rodriguez Andres and Carlyn Ramlogan-Dobson, Corruption, privatisation and the distribution of income in Latin America

2008/10 Stephen Dobson and Carlyn Ramlogan, Is there an openness Kuznets curve? Evidence from Latin America

2008/9 Stephen Dobson, John Goddard and Frank Stähler, Effort levels in contests: an empirical application of the Tullock model

2008/8 Juan Carlos Cuestas and Estefania Mourelle, Nonlinearities in real exchange rate determination: Do African exchange rates follow a random walk?

2008/7 Stephen Dobson and John Goddard, Strategic behaviour and risk taking in football

2008/6 Joao Ricardo Faria, Juan Carlos Cuestas and Estefania Mourelle, Entrepreneurship and unemployment: A nonlinear bidirectional causality?

2008/5 Dan Wheatley, Irene Hardill and Bruce Philp, "Managing" reductions in working hours: $A$ study of work-time and leisure preferences in the UK industry

2008/4 Adrian Kay and Robert Ackrill, Institutional change in the international governance of agriculture: a revised account

2008/3 Juan Carlos Cuestas and Paulo José Regis, Testing for PPP in Australia: Evidence from unit root test against nonlinear trend stationarity alternatives

2008/2 João Ricardo Faria, Juan Carlos Cuestas and Luis Gil-Alana, Unemployment and entrepreneurship: A Cyclical Relation

2008/1 Zhongmin Wu, Mark Baimbridge and Yu Zhu, Multiple Job Holding in the United Kingdom: Evidence from the British Household Panel Survey

\section{DISCUSSION PAPERS IN POLITICAL ECONOMY}

2006/3 Ioana Negru, On Homogeneity and Pluralism within Economics Schools of Thought

2006/2 David Harvie and Bruce Philp, Learning and Assessment in a Reading Group Format or Reading Capital... For Marks

2006/1 David Harvie, Bruce Philp and Gary Slater, Regional Well-Being and 'Social Productivity' in Great Britain'

2004/2 Massimo De Angelis and David Harvie, Globalisation? No Question: Foreign Direct Investment and Labour Commanded 
2004/1 David Harvie, Value-Production and Struggle in the Classroom, or, Educators Within, Against and Beyond Capital

\section{DISCUSSION PAPERS IN APPLIED ECONOMICS AND POLICY}

2007/2 Juan Carlos Cuestas, Purchasing Power Parity in Central and Eastern European Countries: An Analysis of Unit Roots and Non-linearities

2007/1 Juan Carlos Cuestas and Javier Ordóñez, Testing for Price Convergence among Mercosur Countries

2006/2 Rahmi Cetin and Robert Ackrill, Foreign Investment and the Export of Foreign and Local Firms: An Analysis of Turkish Manufacturing

2006/1 Robert Ackrill and Adrian Kay, The EU Financial Perspective 2007-2013 and the Forces that Shaped the Final Agreement

2004/5 Michael A. Smith, David Paton and Leighton Vaughan-Williams, Costs, Biases and Betting markets: New evidence

2004/4 Chris Forde and Gary Slater, Agency Working in Britain: Character, Consequences and Regulation

2004/3 Barry Harrison and David Paton, Do 'Fat Tails' Matter in GARCH Estimation? Stock market efficiency in Romania and the Czech Republic

2004/2 Dean Garratt and Rebecca Taylor, Issue-based Teaching in Economics

2004/1 Michael McCann, Motives for Acquisitions in the UK

2003/6 Chris Forde and Gary Slater, The Nature and Experience of Agency Working in Britain

2003/5 Eugen Mihaita, Generating Hypothetical Rates of Return for the Romanian Fully Funded Pension Funds

2003/4 Eugen Mihaita, The Romanian Pension Reform

2003/3 Joshy Easaw and Dean Garratt, Impact of the UK General Election on Total Government Expenditure Cycles: Theory and Evidence

2003/2 Dean Garratt, Rates of Return to Owner-Occupation in the UK Housing Market

2003/1 Barry Harrison and David Paton, The Evolution of Stock Market Efficiency in a Transition Economy: Evidence from Romania 